ry oraz stanowi najdojrzalszy na gruncie Starego Przymierza etap rozwoju biblijnej idei Wyjścia. Hagiograf przewartościował historię Wyjścia w dzieje konfliktu dobrych ze złymi, dając poglądową naukę o Bożej Opatrzności.

Poznań

KS. BOGDAN PONIŻY

\title{
KS. JACEK KUCHARSKI, Spocząć ze swymi przodkami, Lublin 1998, Wydawnictwo KUL, s. 196
}

Opublikowana przez Wydawnictwo KUL rozprawa ks. Jacka Kucharskiego Spocząć ze swymi przodkami uzupełniła lukę w polskiej literaturze z zakresu zwyczajów, kultu i kultury izraelskiej oraz rzuciła światło na funeralne zwyczaje opisywane na kartach Pisma Świętego. Stało się to dlatego, jak pisze Autor we wstępie: „Człowiek jest niemal przekonany o istnieniu życia pozagrobowego, które będąc dla niego może jeszcze odległą perspektywą, jest postrzegane zarazem jako tajemnica, przeniknięta ogromnym szacunkiem [...]. Podstawową formą oddawania czci zmarłym było i jest grzebanie ciał, powiązane z obrzędem o charakterze religijnym, które niejednokrotnie posiada specjalne prawa. Ceremonie pogrzebowe są zjawiskiem powszechnym" (s. 9).

Publikacja złożona jest ze wstępu i czterech rozdziałów. We Wstępie Autor zaanonsował: „Przy analizie tekstów NT mówiących o grzebaniu zmarłych obok wykopalisk archeologicznych jest uwzględniona również wczesna tradycja rabinistyczna zawarta w Misznie, którą jeden ze znawców określił jako zbiór czterowiekowej tradycji religijnej judaizmu, panującej w Palestynie począwszy od połowy II wieku przed Chr. do II w. po Chr. oraz prawodawstwo wyrażone w innych częściach Talmudu" (s. 13).

Autor rozważania rozpoczął od charakterystyki wierzeń i wynikających z nich zwyczajów funeralnych Starożytnego Wschodu: Mezopotamii, Egiptu, Syrii i Palestyny. Zrobił to dlatego, gdyż zwyczaje pogrzebowe Izraelitów miały wiele wspólnych elementów z tymi zwyczajami u innych starożytnych narodów. Analizując zebrany materiał badawczy ukazał rozwój praktyk pogrzebowych oraz ich wspólne źródła. Przy tym przekazał wiadomości o kulcie zmarłych, zabytkach sakralnych i grobach $\mathrm{z}$ różnych środowisk tych czasów. Wykorzystał w rozprawie wyniki badań archeologicznych na terenie Palestyny, opublikowane w pracach R. de Vaux, A. G. Barroisa, S. Mędali, S. Gądeckiego i wielu innych.

Drugi rozdział poświęcony został zwyczajom izraelskim w oparciu o przekaz Starego Testamentu, ale także przy wykorzystaniu przekazów pozabiblijnych. Znalazły tu swoją analizę nie tylko obrzędowość pogrzebowa występująca u Izraelitów, czynności przygotowawcze do pogrzebu, grobu, żałobnych rytów, ale również informacje dotyczące postów i przepisów pokarmowych oraz żałobnego lamentu. 
Natomiast trzeci rozdział skoncentrował uwagę Autora na tych samych problemach ale w Nowym Testamencie, wykazując jaka nastąpiła ewolucja w ciągu czasu. Sięgając do Ewangelii i Dziejów Apostolskich wykazał, w jakim stopniu Żydzi zachowali dziedzictwo i tradycję ojców, a potem jak przychylili się do zwyczajów niesionych przez Greków i Rzymian.

Ostatni rozdział poświęcono pogrzebowi Jezusa. Omawia w nim problem przygotowania do pogrzebu ciała Jezusowego, miejsca i czasu, biorąc pod uwagę, że było to ciało skazanego, wobec którego prawo żydowskie było ściśle określone.

Zamieszczona bibliografia umożliwia indywidualne poszerzenie wiadomości na powyższy temat.

Pozycja ta warta jest przestudiowania. Powinna zainteresować nie tylko biblistów ale również liturgistów, historyków a nawet prawników. Godna polecenia do włączenia w księgozbiór bibliotek nie tylko uniwersyteckich ale również szkolnych.

Kraków

KS. TADEUSZ MATRAS

\section{Życie religijne w Biblii, redaktor ks. Gabriel Witaszek, wyd. KUL, Lublin 1999.}

Czytając Biblię, zwłaszcza Stary Testament, bez przygotowania naukowego, trudno jest zrozumieć ówczesne struktury życia społecznego i rolę religii w życiu tamtych ludów i społeczeństw. Ułatwia to wydana przez KUL praca Życie religijne w Biblii. Wykładowcy Instytutu Biblijnego tejże uczelni po opracowaniu Życia społecznego $w$ Biblii, w tym dziele ukazują funkcje podstawowych elementów życia religijnego w ramach społeczności Izraela. Tematykę pracy podzielono na cztery działy: (1) miejsca kultu, (2) osoby poświęcone służbie Bożej, (3) akty kultu, (4) czasy święte.

Poszczególne rozdziały tych części opracowali bibliści: S. Bielecki, A. Kondracki, H. Langkammer, A. Mozgol, A. Paciorek, B. Poniży, R. Rubinkiewicz, R. Sikora, U. Szwarc, S. Szymik, A. Tronina, G. Witaszek i H. Witczyk.

Pierwsza część książki poświęcona miejscom kultu religijnego w Izraelu, prezentuje najpierw poszczególne miejsca czci Boga i sanktuaria lokalne, aby w drugim rozdziale omówić rolę Arki Przymierza i Jej teologiczne znaczenie w kulcie, utrwalone przez poszczególne tradycje Pięcioksięgu. Następne rozdziały zajmują się świątynią jako miejscem kultu na starożytnym Bliskim Wschodzie w ogóle, a świątyni jerozolimskiej w szczególności. Teologia świątyni, jako znaku Bożej obecności prowadzi do ukazania jej symboliki w Nowym Testamencie i czasach Kościoła. 